\title{
Schwann Cells Promote Prevascularization and Osteogenesis of Tissue-engineered Bone via Bone Marrow Mesenchymal Stem Cell-derived Endothelial Cells
}

Research

Keywords:

Posted Date: October 19th, 2020

DOI: https://doi.org/10.21203/rs.3.rs-89984/v2

License: (1) This work is licensed under a Creative Commons Attribution 4.0 International License. Read Full License

Version of Record: A version of this preprint was published at Stem Cell Research \& Therapy on July 7th, 2021. See the published version at https://doi.org/10.1186/s13287-021-02433-3. 


\section{Abstract}

The authors have requested that this preprint be withdrawn due to author disagreement.

\section{Full Text}

The authors have withdrawn this preprint from Research Square. 